\author{
Associate Professor Corina - Ionela DUMITRESCU, PhD \\ E-mail: cordumitrescu@yahoo.com \\ Economics Department, Faculty of Entrepreneurship \\ Business Engineering and Management, \\ University POLITEHNICA of Bucharest \\ Assistant Ioana-Ruxandra LIE, PhD \\ E-mail: ruxandra.lie@gmail.com \\ Economics Department, Faculty of Entrepreneurship \\ Business Engineering and Management \\ University POLITEHNICA of Bucharest \\ Associate Professor Eugene MICHAELS, PhD \\ E-mail: e.i.michaels@derby.ac.uk \\ College of Business, Law and Social Sciences, University of Derby
}

\title{
BURDEN-SHARING AND ACCOMMODATION OF MIGRANTS IN THE EU - A SIMULATION BASED ON FACTORIAL DESIGNS
}

\begin{abstract}
In recent years, migration to European countries has intensified like never before, raising issues regarding cooperation in order to manage the situation. The aim of this paper is to simulate the implications for the cooperation between countries using the Vickrey-Clarke-Groves (VCG) mechanism and statistical analysis. In the simulation, we identify the consequences of various decisions of the countries involved in accommodating migrants. We conclude that the types of migrants and partners willing to cooperate can influence on the groups accommodated first, and that the decision to cooperate can influence on the political situation and budgets of receiving countries.

Keywords: European migration, refugees, Vickrey-Clarke-Groves mechanism, Clarke tax, factorial design, analysis of variance, Arrow-Debreu, pure securities.
\end{abstract}

JEL Classification: C49, F22, J15

\section{Introduction}

Between 2014 and 2017, the European Union has taken in 4 million asylum seekers (OECD, 2018), and overall migration (including illegal migration) is probably at a much higher level. The European Union (EU) presents itself as an area of protection, where the right to asylum is upheld and the obligation to grant it is respected (European Commission, 2019). The EU is the destination most of the asylum seekers in the world choose in their flight from persecution in their own

DOI: 10.24818/18423264/54.2.20.09 
countries (over six million people asking for asylum in the last two decades Hatton, 2015). In addition to asylum seekers, many migrants from Eastern Europe, Asia and Africa also choose to the EU in their search for a better and more secure life. The relatively recent spike in inflows from these two sources has raised insecurity fears and suspicion in the destination countries' local populations, leading to political reactions and many difficult debates on how to handle the immigration crisis. The brunt of this migration wave had to be borne by EU border countries (Greece, Italy, Spain), and also by Germany, which is an attractive target due to its wealth and high standard of living. As a consequence, EU countries are squabbling over migrants' quotas due to the lack of a redistribution mechanism.

The European Union has shown in the last decades that it values cooperation and is constantly trying to learn the lessons from working for a common goal - witness its Global Approach to Migration and Mobility (GAMM). The aim of this paper is to show how different factors can influence the decision of cooperation between countries that host migrants to improve the life of the migrants without endangering their own political stability and welfare systems. In order to achieve this goal, we ran a simulation using real data along with some assumptions where information was not available.

We conclude that, for each country, the type (origin) of migrants reaching its territory is important, and that cooperation can influence the order in which these migrants are attended to. We also reach the conclusion that the aid for accommodating migrants can be seen as an investment in the future of the European economies and we show how different decisions and strategies influence which group of migrants is accommodated first, and, consequently, the countries first receiving them.

The structure of the article is as follows. Section 2 presents in brief the main challenges and opportunities faced by European countries when it comes to migration and overviews the ideas proposed so far regarding cooperation between EU members to accommodate migrants, especially refugees and asylum seekers. Section 3 presents the methodology in our analysis of cooperation for solving the migrants' problem. Section 4 discusses the results from our simulation on cooperation, focusing on how cooperation and decision-making influence the situations of both migrants and host countries. We end the article with conclusions and directions for further research.

\section{Literature review}

European migration has been a subject of growing interest in the last few years, with increasing number of migrants, refugees and asylum seekers attempting to and arriving in European Union countries. This led to many internal and international discussions regarding who should be allowed in the EU, how many of them can be accepted and accommodated and, crucially in the last couple of years, where should the migrants be located/relocated. Before offering a solution to the 
Burden-Sharing and Accommodation of Migrants in the EU - A Simulation Based on Factorial Designs

first and last questions, we think it is essential to present the most important legal aspects regarding migration and, also, the main characteristics of the migrants and the EU countries' social environment where they live.

Some authors consider that national migration restrictions have huge costs, as cooperation and liberalisation of labour movement across countries comes with gains that are much larger than the likely benefits from liberalization in the traditional areas of goods and capital (Moses and Letnes, 2004). While noncooperative national policies may lead to inefficiency, international legal cooperation could help increase efficiency. International cooperation is valuable(Petracou et al, 2018), but there are many obstacles to it. Chiefly among these is the argument that migration liberalization is not a win-win process as some countries may be worse off, the asymmetric information about migrants or the welfare problems related to migration. It is very difficult to settle agreements through which all the countries involved become net beneficiaries (Sykes, 2013).

According to Sykes (2013), the analysis of cooperation on migration can be split into four areas: cooperation on permanent migration, cooperation on temporary migration, cooperation on enforcement of visa restriction and cooperation on the accommodation of refugees. The 1967 UN Protocol Relating to the Status of Refugees states that signatory countries oblige themselves not to return refugees to their country. However, this altruistic behaviour will waver when faced with a flood of refugees and hosting costs seem much higher than cooperation benefits. Cooperation may stall as host countries try to set very strict and high standards for the refugee status and to distinguish between refugees and economic migrants (Sykes, 2013; Moraga and Rapoport, 2015).

Refugee flows affect host economies, with impact on both public finances and labour market but, in general, the effect of refugees on growth is often positive, the effect on wages, employment, and unemployment is likely to be mild, and the fiscal impact of refugee flows is small (Dadush, 2018; European Commission, 2013).

In terms of public finances, on average, the main host countries in Europe have to spend around $€ 10,000$ per asylum seeker for processing and accommodation in the first year of application (OECD, 2017). The costs can be higher for certain countries which are more affected by the refugee flow. However, the financial support needed for refugees should decline over time as the refugees adapt to the cultural and economic conditions in the host countries and start paying in taxes. A recent OECD study found that fiscal effects of migration are small and positive for most OECD countries - i.e. taxes paid by migrants are higher than financial benefits they receive from host governments, and that in the long run labour migration is "neither a major burden nor a major panacea for the public purse'(OECD, 2013).

According to OECD (2017), in 2015, Germany spent $€ 16$ billion $(0.5 \%$ of its GDP) on the 900,000 migrants it received while Sweden spent $€ 6$ billion (1.35\% of its GDP) on its 163,000 asylum seekers. These costs are supported either by the

DOI: 10.24818/18423264/54.2.20.09 
national budget or local government, with social protection and education spending being the most important categories of expenditures for refugees. The host countries with the highest number of refugees have a lot of experience in decentralizing public spending for refugees. For example, in 2017, in Austria, the federal government spent $0.5 \%$ of GDP on refugees, asylum and integration, to which the municipalities added $0.25 \%$ of GDP (OECD, 2017).

The impact on the host country labour market depends on the extent to which the migrants can become part of the labour force, the conditions imposed by the host country regarding the refugee status and the duration of the application process. In the early days of their arrival, the impact is quite small as the participation rates for refugees are very low (OECD, 2018; European Commission, 2013). Access to labour markets is a challenge for refugees as it is opposed by the local workforces who resist changes in the structure of employment in the host countries. When the policy-makers and the public consider that migration has a negative impact on employment, relationships between refugees and the local workforce deteriorate making it more difficult for the refugees to integrate (Sak et al., 2018). On average, in OECD countries, the labour market outcomes for migrants are improving and are now close to the levels for native-born (see table 1.1). However, these averages hide the heterogeneity of migrants; there is a wide range of outcomes by region of origin - for the EU, intra-EU migrants fared significantly better than migrants of Middle Eastern and North African origin (see table 1.2).

Table 1.1. Labour market outcomes in OECD countries, 2017

\begin{tabular}{ccc}
\hline & Employment rate & Unemployment rate \\
\hline OECD Foreign-born & $67.10 \%$ & $9.50 \%$ \\
OECD Natives & $68 \%$ & $7.80 \%$ \\
\hline
\end{tabular}

Between 2014 and 2017, European countries received around 4 million applications (three times more than in the previous four years). Out of these 4 million, an estimated total of around 1.2 million applications will be rejected by the end of 2020. The overall economic impact on the labour force is expected to be less than $0.25 \%$ by the end of 2020, with half of the European countries not experiencing any impact (OECD, 2018). 
Burden-Sharing and Accommodation of Migrants in the EU - A Simulation Based on Factorial Designs

Table 1.2. Labour market outcomes by selected origin in EU28 countries

\begin{tabular}{lcccc}
\hline & \multicolumn{2}{c}{ Employment rate } & \multicolumn{2}{c}{ Unemployment rate } \\
& $\mathbf{2 0 1 2}$ & $\mathbf{2 0 1 7}$ & $\mathbf{2 0 1 2}$ & $\mathbf{2 0 1 7}$ \\
\hline EU28 + EFTA & 67.5 & 70.9 & 12.2 & 9.1 \\
North Africa & 48 & 48.5 & 26.4 & 23.3 \\
Middle East & 51.8 & 49.3 & 20.7 & 22.1 \\
Asia & 62 & 64.9 & 10 & 7.5 \\
North America & 68.9 & 72.1 & 7.2 & 5.8 \\
Foreign-born (total) & 62.2 & 63.4 & 15.5 & 13.1 \\
Native-born & 63.6 & 66.4 & 10.7 & 8.1 \\
\hline
\end{tabular}

Source: OECD (2018)

Despite their importance, discussion of the benefits from immigration has been dominated by debates over the costs of migration (Dadush, 2018; European Commission, 2013). Benefits from migration accrue at both individual and country-level. At an individual level, there are clear benefits: the wages migrants can earn are higher than in their origin countries and there are associated effects on welfare and human development of the migrants' families. At origin country level, there are benefits from emigration in the reduction of the unemployment rate (albeit, countered by the brain-drain effect (European Commission, 2013), and the steady and reliable inflow of migrant remittances which make both migrants and migrants' families from origin countries happier (IOM, 2018). At the same time, the labour supply decreases in the presence of these remittances (Roth and Tiberti, 2017). However, benefits also accrue at host country level as well, in the form of boosts to GDP growth rates, complementary skills for native workers, positive effects on labour market from reducing labour supply shortages (Dadush, 2018; IOM, 2018; European Commission, 2013).

The strategy in OECD countries is to develop integration programmes for migrants and refugees. Obtaining language skills has become a compulsory step in getting a residency or a work permit. Additionally, some countries are developing a collaborative system through which professional skills of migrants can be recognized by employers and social partners in host countries (European Commission, 2013). Simultaneously, many OECD countries tailored measures meant to protect the most vulnerable groups of migrants - those with limited skills or unaccompanied minors (OECD, 2018). However, it is difficult to have a 'one size fits all' integration policy since host countries have different characteristics (Sak et al., 2018).

The EU's Global Approach to Migration and Mobility (GAMM), is an example of international cooperation focused on managing migration, maximizing the development impact of migration and mobility and protecting the refugees and migrants in need. GAMM was adopted in 2005 but was renewed and refocused in 
2011 to better reflect the EU's strategic objectives particularly vis-à-vis its Southern Mediterranean and Eastern Neighbourhood, Africa and EU enlargement countries (European Commission, 2011).

However, while GAMM is concentrated on building partnerships with nonEU countries, significant difficulties remain dealing with the refugees and migrants once they are in the EU. Taking everything into consideration, including the heavy burden on some of its member states, especially those located at the EU's borders (Petracou et al, 2018), the Common European Asylum System (launched in 1999) has been under increasing criticism (Hatton, 2015; Moraga and Rapoport, 2015). The system seems unable to, first, spread the responsibility of accommodating migrants between the EU members and, second, to take into account the migrants' and host countries' preferences for relocation. To help solve this issue, Moraga and Rapoport (2015) propose a market-based solution involving tradable immigration quotas with a matching mechanism for preferences. In their article, Moraga and Rapoport (2015) consider that the migration issue should be analyzed as a problem with a public good, and decisions regarding quotas traded should be made considering the optimal point of the market. Providing asylum is seen as a public good and EU countries should split costs in a more equitable way. While interesting in theory, as it can even take into consideration the countries' and migrants' preferences, we believe that the system they propose is too complicated to be put into practice: it would require a great deal of negotiation between all the EU countries, and also many resources in order to apply the mechanism needed in order to match the countries and migrants.

In order to address the same issue, we take a different approach in accounting for the migrants' and host countries' preferences and the resources available for relocation and accommodation of each type of migrant, and propose a different model that builds a rationale for cooperation within a common European contributions fund and find the optimum contributions for each member country. One disadvantage that our model has, compared to Moraga and Rapoport's is the fact that our simulation assumes the countries' and immigrants' preferences, because of the lack of data. In spite of it, this obstacle can be easily overcome if the model is used by governments, who do have access to relevant data.

\section{Materials and Methods}

In order to simulate how the European countries should cooperate in accommodating migrants, we used data extracted from media sources and public research output (OECD, 2017; Agencia EFE, 2018 and BBC, 2018) in order to generate a realistic set of data that fit our design. Despite using real-based but generated data, this simulation can be a starting point for further research, as the statistical methods we employ can be just as easily used on real data should it become available. 
Burden-Sharing and Accommodation of Migrants in the EU - A Simulation Based on Factorial Designs

In our analysis, we follow a statistical analysis process established in Mihăiţă (1985). We start by using a Latin square design (Cochran and Cox, 1957) to essentially mimic the preferences in immigration based on simulated data generated from real sources. The design allows us to control for three sources of variation: the origin of migrants, the host countries and the amount of money allocated for their accommodation.

Table 3.1. The Latin Square Design

Contributions Origin of migrants

\begin{tabular}{clllll}
\multicolumn{1}{c}{} & \multicolumn{1}{c}{$\boldsymbol{y}$} & 1 & 2 & 3 \\
\cline { 3 - 5 } Host countries & 1 & $\mathrm{a}$ & $\mathrm{b}$ & $\mathrm{c}$ \\
& 2 & $\mathrm{c}$ & $\mathrm{a}$ & $\mathrm{b}$ \\
& 3 & $\mathrm{~b}$ & $\mathrm{c}$ & $\mathrm{a}$ \\
\cline { 5 - 5 } & & &
\end{tabular}

We then use a Vickrey-Clarke-Groves (VCG) mechanism with a Clarke tax for making social choices as employed by Tideman and Tullock (1976) in order analyse the impact of withdrawing from cooperation for each of the countries identified. Given the Latin square design, all our host countries have the potential to be 'pivotal' and incur a penalty (a Clarke incentive tax) calculated for each host country by removing them from the square and identifying the net contributions for the remaining cooperating countries.

Our aim is to identify the combination of contribution allocations that ensure all migrants are accommodated in the same way (treated equally) regardless of their origin and their host country. To this end, we return to analyzing the sources of variation in our data using ANOVA.

Following Cochran and Cox (1957), the standard statistical model associated with the Latin square design is

$$
X_{i j k}=\mu+\alpha_{i}+\beta_{j}+\tau_{k}+\epsilon_{i j k}
$$

where $\mu$ is the baseline mean, $\alpha_{i}$ is the effect due to treatment $\mathrm{i}, \beta_{j}$ is the effect due to row $\mathrm{j}, \tau_{k}$ is the effect for column $\mathrm{k}$, and $\epsilon_{i j k}$ is a random error, with $\mathrm{i}, \mathrm{j}, \mathrm{k}$ ranging from 0 to $t$.

Consequently, the ANOVA for the three factors is calculated as follows:

$$
\begin{aligned}
& S S_{\text {Total }}=\sum_{i=1}^{t} \sum_{j=1}^{t} \sum_{k=1}^{t} \frac{X_{i j k}^{2}}{t}-\frac{G^{2}}{t^{2}} \\
& S S_{\text {treatment }}=\sum_{i=1}^{t} \frac{T_{i}^{2}}{t}-\frac{G^{2}}{t^{2}} \\
& S S_{\text {rows }}=\sum_{j=1}^{t} \frac{R_{j}^{2}}{t}-\frac{G^{2}}{t} \\
& S S_{\text {columns }}=\sum_{k=1}^{t} \frac{C_{k}^{2}}{t}-\frac{G^{2}}{t^{2}}
\end{aligned}
$$


where $\mathrm{SS}_{\text {total }}$ is the total sum of squares, $y_{i j k}$ is the observation from the ith row, jth column and with the kth treatment, $\mathrm{G}$ is the grand total, $\mathrm{SS}_{\text {treatment }}$ is the treatment sum of squares, $T_{i}$ is the $i^{\text {th }}$ row total, $S S_{\text {rows }}$ is the row sum of squares, $B_{j}$ is the $j^{\text {th }}$ row total, $\mathrm{SS}_{\text {columns }}$ is the column sum of squares, $\mathrm{C}_{\mathrm{k}}$ is the $\mathrm{k}^{\text {th }}$ column total and $\mathrm{t}$ is the number of rows, columns or treatments.

We use F-test at 5\% level of significance to check for significant differences between the means.

We then re-interpret the simulation data in Table 3.1 from the perspective of the state-preference framework (Arrow, 1964; Debreu, 1959). Each host country faces uncertainty in the form of not knowing the origin of the migrants it will receive. Thus, the sources of migration become the 'states of nature' of the framework (assumed to be mutually exclusive) while the Latin square values become a matrix of state-contingent payoffs (to the migrants).

$$
A=\left(\begin{array}{lll}
a & b & c \\
c & a & b \\
b & c & a
\end{array}\right)
$$

We follow the procedure identified in Copeland, Weston and Shastri (2013) to derive the prices for 'pure cooperation contributions' ('pure securities' in Arrow-Debreu parlance) - combinations of contributions that would pay 1 euro at the end of the period if a given state of the world occurs and nothing otherwise, for example $(1,0,0)$. Linear combination of such 'pure combinations of contributions would make up a host country's set of state-contingent portfolio payoffs. We further assume that the 'securities market' is complete - i.e. the combinations of contributions are linearly independent, and so the determinant of the payoff matrix is non-zero. In order to generate the 'pure cooperation contributions' (pure securities) we will need to find the inverse matrix $\left(\mathrm{A}^{-1}\right)$ :

$$
A^{-1} A=I \text { where } I=\left(\begin{array}{lll}
1 & 0 & 0 \\
0 & 1 & 0 \\
0 & 0 & 1
\end{array}\right)
$$

$P$ in

The 'pure prices' for the 'pure securities' are then calculated as the vector

$P=A^{-1} C$
where $P=\left(\begin{array}{l}p_{1} \\ p_{2} \\ p_{3}\end{array}\right)$ is the vector of pure prices and $C=\left(\begin{array}{l}c_{1} \\ c_{2} \\ c_{3}\end{array}\right)$ is a notional vector of equal contributions from each country.

Essentially, the $\mathrm{A}^{-1}$ matrix contains the instructions for combining the countries' contributions for ensuring the equal treatment of migrants. The column totals of the $\mathrm{A}^{-1}$ matrix give the ratios for optimization so that each 'state' (source of migration) has the same likelihood of happening. Once we ensure that each source of migration is equally likely to happen (and be accommodated), we need to minimize the variance of the payoffs for each source of migration. Essentially, we need to find the value of the vector $\mathrm{C}$ as a solution for the matrix system above that 
Burden-Sharing and Accommodation of Migrants in the EU - A Simulation Based on Factorial Designs

allows the sum of the pure prices to add to 1 (euro). We then test the goodness-offit using Chi-square.

Finally, based on the inverse matrix instructions we generate the new set of contribution allocations that will equalize the treatment of migrants regardless of their origin.

\section{Results and discussion: Simulation for accommodation of migrants in $\mathrm{EU}$ countries}

We consider three countries as favorite destinations for migrants: Germany, Greece, and Spain. We also consider that there are three main types of refugees and migrants that arrive in Europe: African, Syrian and Middle-Eastern, and Eastern European. We took into account the sums spent for migrants in the three countries and generated the table 4.1 showing the sums each country was willing to spend in order to accommodate each type of migrants. Where the data was not available we used the fact that each migrant costs the host country around 10.000 Euros in the first year from their arrival (OECD, 2017) By implication, the table also shows which type of migrants are most likely to end up in each country, and each country's priorities for accommodating each type (which type is accommodated first). Given the sums of money allocated, it looks like each country has a preferred type of migrants, allocating money for their accommodation either because they are perceived as a 'better-fit' in their own societies or simply because that, historically, it was mostly migrants from that origin arriving in their country, so they would like to solve their situation first. As a result, the data fits the Latin square design, with both the migrants and the host countries revealing ranked preferences in their choices.

Table 4.1. Country budgets for the accommodation of migrants (millions of Euros)

\begin{tabular}{ccccc} 
& Africa & $\begin{array}{c}\text { Middle } \\
\text { East }\end{array}$ & $\begin{array}{c}\text { Eastern } \\
\text { Europe }\end{array}$ & Total \\
\hline Spain & 100 & 50 & 50 & 200 \\
Greece & 44 & 100 & 56 & 200 \\
Germany & 2080 & 2320 & 3600 & 8000 \\
Total & 2224 & 2470 & 3706 & 8400 \\
\hline
\end{tabular}

Source: Authors' calculations based on data from OECD (2017), Agencia EFE (2018) and BBC (2018)

From a total of 200 million euro allocated, Spain is open to spend twice as much for migrants coming from Africa (presumably on twice as many migrants) than for migrants originating in the other two areas. Greece, on the other hand, budgets the same overall amount but prioritizes spending on migrants from Middle

DOI: 10.24818/18423264/54.2.20.09 
East. While the overall amounts for Germany dwarf the allocations of the other two countries, it too reveals a willingness to spend more on Eastern European migrants (45\% of the 8000 million euro budget) than from the other two sources of migration (26\% Africa and 29\% Middle East).

We further assume that the three countries decide to cooperate on how to best allocate resources to accommodate their preferred migrants. Given the sums involved and the fact that Germany was, in fact, the final destination for most of the migrants, we will consider that Germany would benefit from participating in a cooperation agreement in order to make a preliminary selection of the migrants. Germany would contribute an amount similar to the other two countries to be used for accommodating and checking migrants passing through Greece and Spain and having as final destination Germany. We simulate a German contribution 210 million Euros (approximately $2.5 \%$ from the 8000 million Euros estimated) split between the migrant types in keeping with the same proportions as in Table 4.1.

As a result, the starting point in our simulation analysis is Table 4.2 which restates the budgets for Greece and Spain alongside the new figures generated for Germany, as part of a cooperation agreement.

Table 4.2. Country contributions to cooperation agreement on migrants

\begin{tabular}{ccccc} 
& Africa & $\begin{array}{c}\text { Middle } \\
\text { East }\end{array}$ & $\begin{array}{c}\text { Eastern } \\
\text { Europe }\end{array}$ & Total \\
\hline Spain & 100 & 50 & 50 & 200 \\
Greece & 44 & 100 & 56 & 200 \\
Germany & 50 & 60 & 100 & 210 \\
Total & 194 & 210 & 206 & 610 \\
\hline
\end{tabular}

Source: Authors' calculations based on data from OECD (2017), Agencia EFE (2018) and BBC (2018)

\subsection{Considerations on cooperation}

Having generated the data, we set out to analyze the consequences of the withdrawal of one of the partners, using the VCG mechanism. When one country withdraws (i.e. it decides to deal with its preferred type of migrants separately) a different category of migrants becomes the priority and needs to be sorted by the remaining two. The Clarke tax penalizes the withdrawing country to the amount necessary for the remaining two countries to begin accommodating the new category of planned migrants. The tax is an incentive to keep cooperating however, there may be savings left from withdrawing even after deducting the tax. Table 4.3 shows the results of applying the VCG mechanism. 
Burden-Sharing and Accommodation of Migrants in the EU - A Simulation Based on Factorial Designs

Table 4.3. Contribution withdrawal and VCG incentive-compatible mechanism

\begin{tabular}{ccccccc} 
& Africa & $\begin{array}{c}\text { Middle } \\
\text { East }\end{array}$ & $\begin{array}{c}\text { Eastern } \\
\text { Europe }\end{array}$ & Penalty & Savings & $\begin{array}{c}\text { Get } \\
\text { Gains }\end{array}$ \\
\hline Greece + Germany & 94 & 160 & 156 & 0 & 50 & 50 \\
Spain + Germany & 150 & 110 & 150 & 40 & 56 & 16 \\
Spain + Greece & 144 & 150 & 106 & 0 & 60 & 60 \\
& & & Alternative & 40 & 44 & 4 \\
\hline
\end{tabular}

Source: Authors' calculations based on data from OECD (2017), Agencia EFE (2018) and BBC (2018)

By using the VCG mechanism and applying the Clarke tax as a penalty for withdrawal we find the following:

From table 4.2, the total contribution amount for Middle Eastern migrants is the highest at 210, with Greece being targeted as host country; the cooperation agreement will start accommodating Middle-Eastern migrants in their countries first. However, what if, instead of accommodating Middle Eastern migrants, the countries are more interested in accommodating their preferred migrants for whom they had planned the initial accommodation activities? As each country withdraws from the agreement the initial budgets will no longer be available and strategic alternatives must be explored. We take them one at a time.

a) If Spain withdraws in order to focus on accommodating African migrants, only Greece and Germany contribute to the cooperation agreement. The new totals become 94, 160 and 156 respectively for Africa, Middle East and Eastern Europe. The largest amount is still destined for Middle Eastern migrants, but the burden of operations is taken over by Greece, which has experience in accommodating this type of migrants. Since Spain's withdrawal does not change the outcome of Middle-Eastern migrants being 'winners', there is no penalty for Spain; for now it 'saved' 50 million Euros (Spain now only has to focus on Africa and Eastern Europe, totaling 150 million euro).

b) If Germany withdraws in order to focus on accommodating Easter European migrants, only Spain and Greece remain cooperating. The total amounts remaining in the budgets become 144 for Africa, 150 million for Middle East and 106 for Eastern Europe. Under these circumstances, Spain and Greece will still focus on receiving Middle Eastern migrants, with Greece being the main target host country; Germany will save 60 million Euros.

c) If Greece withdraws (presumably unable to honor the contribution promises made, since their priority is the migrants coming from Middle East anyway), only Spain and Germany are left cooperating. The new total amounts left available to Spain and Germany are now 150 for Africa, 110 million for Middle East and 150 million for East Europe. Greece's withdrawal changes the outcome for the

DOI: 10.24818/18423264/54.2.20.09 
cooperation agreement - migrants from either Africa or Eastern Europe can become a priority (each with the same higher total of 150 million euro). Spain and Germany will now save 100 million from not accommodating Middle Eastern migrants (who were Greece's priority).

- If Spain insists that African migrants become the priority, covered to the full 194 million promised initially, Spain and Germany will have saved 56 million (100 million from not focusing on Middle East - 44 million going towards African migrants). Also, since the amounts originally planned for Middle East now amount to only 110 million compared with the 150 million Euros needed for the others, Greece must be penalized with the difference of 40 million euro.

- If, on the other hand, Germany insists the Eastern European migrants become the priority, covered to the full 206 million euro promised initially, Spain and Germany will have saved 44 million (100 million from not focusing on Middle East - 56 million going towards Eastern European migrants). Again, since the amounts originally planned for Middle East now amount to only 110 million compared with the 150 million Euros needed for the others, Greece must be penalized with the difference of 40 million euro.

The bottom line is that there are clear incentives for all three host countries to withdraw from cooperation to focus solely on their preferred migrants. Spain and Greece would benefit from additional incentives to keep them inside the agreement, to help them accommodate their preferred migrants while filtering the other migrants destined for the other countries.

\subsection{Considerations on the equal treatment of migrants}

We now turn to ensuring the migrants are treated equally, regardless of their origin, using derivation of pure securities in the state-preference framework. Starting with table 4.2 , we identify the expected values and test the data for goodness-of-fit using Chi-squared.

Table 4.4. Expected values for country contributions to cooperation agreement on migrants

\begin{tabular}{cccc} 
& Africa & $\begin{array}{c}\text { Middle } \\
\text { East }\end{array}$ & $\begin{array}{c}\text { Eastern } \\
\text { Europe }\end{array}$ \\
\hline Spain & 64 & 69 & 68 \\
Greece & 64 & 69 & 68 \\
Germany & 67 & 72 & 71 \\
Total & 194 & 210 & 206
\end{tabular}

Source: Authors' calculations based on data from OECD (2017), Agencia EFE (2018) and BBC (2018) 
Burden-Sharing and Accommodation of Migrants in the EU - A Simulation Based on Factorial Designs

Testing at a level of significance $\alpha$ of 0.05 and 4 degrees of freedom gives a p-value of $1.47747 \times 10^{\wedge}-14$ and a test statistic of 70.88 (higher than the $X^{2}$ critical value of 9.4877) so, as expected, we reject the null hypothesis and confirm the countries have specific preferences in terms of origin of migrants. However, the expected values (of about 68 million euro) in the case of independence (null hypothesis), give us a good benchmark for the equal treatment of migrants resulting from cooperation.

We then proceed to identify the elements that solve the equation (8) - the inverse matrix and the vectors for pure prices and equal contributions (table 4.5).

Table 4.5. Inverse matrix, pure prices and equal contributions

\begin{tabular}{ccccc} 
& Africa & $\begin{array}{c}\text { Middle } \\
\text { East }\end{array}$ & $\begin{array}{c}\text { Eastern } \\
\text { Europe }\end{array}$ & $\begin{array}{c}\text { Equal } \\
\text { contributions }\end{array}$ \\
\hline Spain & 0.0142 & -0.0043 & -0.0047 & $\mathbf{6 7 . 7 3}$ \\
Greece & -0.0034 & 0.0161 & -0.0073 & $\mathbf{6 7 . 7 3}$ \\
Germany & -0.0051 & -0.0075 & 0.0167 & $\mathbf{6 7 . 7 3}$ \\
Total & $\mathbf{0 . 0 0 5 8}$ & $\mathbf{0 . 0 0 4 3}$ & $\mathbf{0 . 0 0 4 7}$ & $\mathbf{2 0 3 . 1 9}$ \\
& $\mathbf{3 9 \%}$ & $\mathbf{2 9 \%}$ & $\mathbf{3 2 \%}$ & \\
\hline
\end{tabular}

Source: Authors' calculations based on data from OECD (2017), Agencia EFE (2018) and BBC (2018)

We can test the solution - multiplying the initial contribution matrix (table 4.2) with the vector of pure prices give us the vector of equal contributions:

$$
\left(\begin{array}{ccc}
100 & 50 & 50 \\
44 & 100 & 56 \\
50 & 60 & 100
\end{array}\right) \times\left(\begin{array}{l}
0.355 \\
0.363 \\
0.282
\end{array}\right)=\left(\begin{array}{l}
67.73 \\
67.73 \\
67.73
\end{array}\right)
$$

We interpret the pure prices and the pure securities ('pure cooperation contributions') as follows. A pure security for Spain would pay 1 euro if a migrant is from Africa and nothing if a migrant is from Middle East or Eastern Europe $(1,0,0)$. The pure price of such a security is 35.5 cents. Similarly, a pure security for Greece would pay 1 euro if a migrant is from Middle East and nothing if a migrant is from Africa or Eastern Europe $(0,1,0)$. The pure price of such a security is 36.3 cents. It follows that it is more cost-effective to accommodate Eastern European migrants in Germany than to accommodate Middle Eastern migrants in Greece.

The inverse matrix instructions would see 203.2 million euro split as follows: 79 million euro (39\% of 203.2 million euro) would go to Spain for accommodating African migrants, 59 million euro (29\% of 203.2 million euro) would go to Greece for accommodating Middle Eastern migrants, and 65 million euro would be spent on Eastern European migrants in Germany.

DOI: 10.24818/18423264/54.2.20.09 
Corina-Ionela Dumitrescu, Ioana-Ruxandra Lie, Eugene Michaels

Table 4.6. Allocations to cooperation agreement on migrants

\begin{tabular}{cccc} 
& Africa & $\begin{array}{c}\text { Middle } \\
\text { East }\end{array}$ & $\begin{array}{c}\text { Eastern } \\
\text { Europe }\end{array}$ \\
\hline Spain & 79 & 0 & 0 \\
Greece & 0 & 59 & 0 \\
Germany & 0 & 0 & 65
\end{tabular}

Source: Authors' calculations based on data from OECD (2017), Agencia EFE (2018) and BBC (2018)

These amounts would be contingent on the countries making good on their contribution promises stated in table 4.2. The amounts promised relative to the allocations in table 4.6 are:

Table 4.7. Amounts promised relative to the allocations

\begin{tabular}{cccc} 
& Africa & $\begin{array}{c}\text { Middle } \\
\text { East }\end{array}$ & $\begin{array}{c}\text { Eastern } \\
\text { Europe }\end{array}$ \\
\hline Spain & 1.5 & 0.70 & 0.7 \\
Greece & 0.6 & 1.5 & 0.8 \\
Germany & 0.7 & 0.9 & 1.5
\end{tabular}

Source: Authors' calculations based on data from OECD (2017), Agencia EFE (2018) and BBC (2018)

It is essential that the central fund 'invests' in each country's pure security, because this maximizes the gains for all partners involved. Countries need that because cooperation helps ease the burden of receiving migrants, which implies not only financial costs, but political ones too: the rise of far right all over Europe, fighting the core values of the EU.

Table 4.8. Final contributions to cooperation agreement on migrants

\begin{tabular}{cccc} 
& Africa & $\begin{array}{c}\text { Middle } \\
\text { East }\end{array}$ & $\begin{array}{c}\text { Eastern } \\
\text { Europe }\end{array}$ \\
\hline Spain & 116.9 & 58.4 & 58.4 \\
Greece & 38.4 & 87.2 & 48.8 \\
Germany & 48.0 & 57.6 & 95.9 \\
Total & 203.2 & 203.2 & 203.2 \\
\hline
\end{tabular}

Source: Authors' calculations based on data from OECD (2017), Agencia EFE (2018) and BBC (2018) 
Burden-Sharing and Accommodation of Migrants in the EU - A Simulation Based on Factorial Designs

\section{Conclusions}

As more and more people reach European countries in search for a better life, the need to cooperate in order to accommodate all of them becomes more and more important. The aim of this paper is to show how cooperation can be analysed, how researchers can identify and verify the interactions between different factors that influence decisions regarding migrants.

We conclude that the aid for accommodating migrants can be seen as an investment in the future of the European economies: the migration process has slowed down, but will not disappear as long as there are parts of the world where war and poverty make people leave their homes in search for a better life; that is why for the European countries would be better to be prepared for receiving, verifying and accommodating these migrants in such a way that their own communities will not risk losing peace and welfare. We show that communication and cooperation are important, and that changing your mind after agreeing to cooperation can have serious consequences on what group of migrants is accommodated first and can also bring penalties for those who do not comply with agreements. Our study also shows that even if a country is not situated at the EU's borders, it would be better to help those who are, because a better preparation and verification at the entrance in the EU can help have fewer problems with migrants afterwards, when they go further to Central and Northern Europe.

We consider that our simulations could have direct influence on the policies drawn by different European countries. If the migration issue was analysed as shown before, policy makers could better plan their actions and thus better manage their available funds. Moreover, knowing what to expect, and relying on their partners, they could also prepare their own population to accept and support the migrants, for a peaceful cohabitation, that benefits all involved parties. In addition, cooperation between states could improve the migrants' checking and supervision, which can provide better security for European citizens, can help prevent terrorism, and therefore create less tension between migrants and Europeans. The analysis shown before can become more than a simulation if used by government authorities, which have access to all the data needed for our calculations.

We believe that our findings can be verified in further research, when data regarding countries intentions and funding for accommodating migrants are publicly available. We would also like, based on the same simulation or using real data, if it becomes publicly available, to apply Onicescu information statistics in order to discover how different factors could influence the decision-making regarding migration, and also the false and hidden relationships between these factors. Moreover, we consider that this methodology can be used, with little changes, in order to analyse other common projects in European countries and regions, as cooperation is one of the basic principles of the European Union.

DOI: 10.24818/18423264/54.2.20.09 
Corina-Ionela Dumitrescu, Ioana-Ruxandra Lie, Eugene Michaels

\section{REFERENCES}

[1] Bernardo, M. J. (2005), Reference Analysis. Handbook of statistics, 25:1790 ;

[2] Chang, C.K., Chang, T. (2012), The Impact of Structural Change on the Calibration of Interest Rates Models in Taiwan. Economic Computation and Economic Cybernetics Studies and Research; ASE Publishing,46(4): 121-142;

[3] Donaldson, W.A. (1977),Inventory Replenishment Policy for a Linear Trend in Demand.Operations Research, 28, 663-670;

[4] Li, K., Lin, Z., Wang, X. (2015), An Empirical Analysis of Users' Privacy Disclosure Behaviors on Social Network Sites; Information \& Management, 52: 882-891.

[5] Agencia EFE (2018), Casi 50.000 migrantes irregulares llegaron a España en 2018, un $154 \%$ más. [Online] Available at https://www.efe.com/efe/espana/sociedad/casi-50-000-migrantes-irregularesllegaron-a-espana-en-2018-un-154-mas/10004-3783521 [Accessed 9 May 2019]; [6] Arrow, K. J. (1964), The Role of Securities in the Optimal Allocation of Risk-Bearing, Review of Economic Studies, 91-96;

[7] BBC (2018), Migration to Europe in Charts. [Online] Available at https://www.bbc.com/news/world-europe-44660699. [Accessed 9 may 2019]; [8] Clarke, E.H. (1971), Multipart Pricing of Public Goods. Public Choice, Volume 11, Issue 1: 17-33;

[9] Cochran, W. G., \& Cox, G. M. (1957), Experimental Designs, (2nd ed.); Oxford, England: John Wiley \& Sons;

[10] Copeland, T.E., Weston, J.F., Shastri, K. (2013), Financial Theory and Corporate Policy, 4th edition, Pearson Education Limited, London;

[11] Dadush, U. (2018), The Economic Effects of Refugee Return.Economics:

The Open-Access, Open-Assessment E-Journal, 12 (2018-33) p. 1-17.

http://dx.doi.org/10.5018/economics-ejournal.ja.2018-33;

[12] Debreu, G. (1959), The Theory of Value. Wiley: New York;

[13] European Commission (2011), Communication from the Commission to the

European Parliament, the Council, the European Economic and Social Committee and the Committee of the Regions - The Global Approach to Migration and Mobility. [online] Available at: https://eur-lex.europa.eu/legalcontent/EN/ALL/?uri=CELEX:52011DC0743 [Accessed 3 May 2019]; [14] European Commission (2013), Using EU Indicators of Immigrant Integration - Final Report for Directorate-General for Home Affairs. [online] Available at https://ec.europa.eu/home-affairs/sites/homeaffairs/files/elibrary/documents/policies/legalmigration/general/docs/final_report_on_using_eu_indicators_of_immigrant_integr ation_june_2013_en.pdf[Accesed 13 June 2019];

[15] European Commission (2019), Common European Asylum System -

Migration and Home Affairs - European Commission. [online] Available at:

DOI: $10.24818 / 18423264 / 54.2 .20 .09$ 
Burden-Sharing and Accommodation of Migrants in the EU - A Simulation Based on Factorial Designs

https://ec.europa.eu/home-affairs/what-we-do/policies/asylum_en [Accessed 13 May 2019];

[16] Groves, T. (1973), Incentives in Teams. Econometrica: Journal of the

Econometric Society, 617-631;

[17] Hatton, T. (2015), Asylum Policy in the EU: The Case for Deeper

Integration, CESifo Economic Studies, 61, issue 3-4: 605-637;

[18] International Organisation for Migration (IOM) (2018), World Migration Report 2018, The UN Migration Agency, [online] Available

athttp://publications.iom.int/system/files/pdf/wmr_2018_en.pdf[Accessed 9 April 2019];

[19] Mihăiţă, N. (1985), Illustration of the Interaction Potential in

Marketing.Economic Computation and Economic Cybernetic Studies and Research, No. 2, Bucharest University of Economic Studies Publishing House, Bucharest;

[20] Moraga, J.F.H., Rapoport, H. (2015), Tradable Refugee-admission Quotas and EU Asylum Policy.CESifo Economic Studies, Vol. 61, 3/2015: 638-672 https://doi.org/10.1093/cesifo/ifu037;

[21] Moses, J. W., Letnes, B. (2004), The Economic Costs to International Labor Restrictions: Revisiting the Empirical Discussion.World Development, Volume 32, Issue 10, October: 1609 - 1626;

[22] OECD (2018), International Migration Outlook 2018. OECD Publishing, Paris. http://dx.doi.org/10.1787/migr_outlook-2018-en;

[23] OECD (2017), Who Bears the Cost of Integrating Refugees, Migration Policy Debates, No. 13 January,http://www.oecd.org/els/mig/migration-policy-debates13.pdf;

[24] OECD (2013), Chapter 3, The Fiscal Impact of Immigration in OECD Countries. In: International Migration Outlook 2013. OECD Publishing, Paris; [25]Petracou, E.V., Domazakis, G.N., Papayiannis, G.I., Yannacopoulos, A.N. (2018), Towards a Common European Space for Asylum. Sustainability, 10, 2961: $1-17$;

[26] Roth, V., Tiberti, L. (2017), Economic Effects of Migration on the Left-

Behind in Cambodia. The Journal of Development Studies, 53:11:1787-1805;

[27] Sak, G., Kaymaz, T., Kadkoy, O., Kenanoglu, M. (2018), Forced

Migrants: Labour Market Integration and Entrepreneurship. Economics:The Open-Access, Open-Assessment E-Journal, 12 (2018-32): 1-13, http://dx.doi.org/10.5018/economics-ejournal.ja.2018-32;

[28] Sykes, A. O. (2013), International Cooperation on Migration: Theory and Practice. University of Chicago Law Review, Vol. 80 : Iss. 1, Article 12: 315 340;

[29] Tideman, T.N., Tullock, G. (1976), A New and Superior Process for Making Social Choices. Journal of Political Economy, 84: 1145-1160; [30] Vickrey, W. (1961), Counter Speculation, Auctions, and Competitive Sealed Tenders. The Journal of finance, 16(1): 8-37.

DOI: 10.24818/18423264/54.2.20.09 